\title{
A New Database on Trait-Based Selection of Stormwater Pond Plants ${ }^{1}$
}

\author{
Gisele P. Nighswander, Mary E. Szoka, Kayla M. Hess, Eban Z. Bean, Gail Hansen de Chapman, \\ and Basil V. lannone III
}

\section{Abstract}

Many master-planned communities, especially in the state of Florida, rely on stormwater ponds for flood control and water treatment. Although these ponds do control flooding effectively, many fall short on water-treatment standards. Planting in and around stormwater ponds may help improve water quality. It may also enhance other ecosystem services that these engineered systems lack. These services can range from improved green-space aesthetics and higher property values to limiting the establishment of invasive plants and the enhancement of wildlife habitat and biodiversity. This document describes a database tool that can be used to facilitate plant selection based on plant traits. The plant species included are intended to be planted in and around stormwater ponds. The plants are characterized based on three trait categories: aesthetics (i.e., appearance), function (i.e., how the species affects and/or responds to the environment), and habitat (i.e., optimal growing conditions). We developed this database with 82 different commercially available plant species that are suited for four different stormwater pond zones-bank top, bank slope, water's edge, and offshore. The database is designed to aid stakeholders in making informed decisions about plant species selection based on important traits for stormwater pond plantings.

\section{Introduction}

Since the implementation of the federal National Pollutant Discharge Elimination System program (NPDES), many states and municipalities have developed programs to control stormwater runoff volumes, prevent flooding, and mitigate pollution of natural water bodies, typically by installing stormwater ponds (EPA 2009). Florida, in particular, has many master-planned communities, which include engineered ponds designed to achieve these functions (Ott et al. 2015; Figure 1). The strong push to construct these ponds, however, has often been followed by limited maintenance (EPA 2009). Stormwater ponds are installed in urban areas to provide the two main functions/ecosystem services of flood control and water treatment (i.e., to collect and/ or uptake sediments, nutrients, pollutants running off of urban landscapes and prevent them from entering natural water bodies) (Harper and Baker 2007). While stormwater ponds can control flooding effectively, their ability to prevent nutrients and other pollutants from entering natural water bodies varies depending upon several factors including retention time (Rushton et al. 1997; Harper and

1. This document is FA216, one of a series of the Program in Fisheries and Aquatic Sciences, School of Forest Resources and Conservation, UF/IFAS Extension. Original publication date June 2019. Visit the EDIS website at https://edis.ifas.ufl.edu for the currently supported version of this publication.

2. Gisele P. Nighswander, MS student, School of Forest Resources and Conservation; Mary E. Szoka, MS graduate, Department of Agricultural and Biological Engineering; Kayla M. Hess, MS student, School of Forest Resources and Conservation; Eban Z. Bean, assistant professor, Department of Agricultural and Biological Engineering; Gail Hansen de Chapman, associate professor, Environmental Horticulture Department; and Basil V. Iannone III, assistant professor, Program in Fisheries and Aquatic Sciences, School of Forest Resources and Conservation; UF/IFAS Extension, Gainesville, FL 32611.

The Institute of Food and Agricultural Sciences (IFAS) is an Equal Opportunity Institution authorized to provide research, educational information and other services

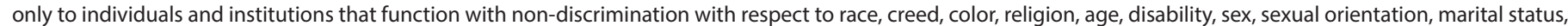

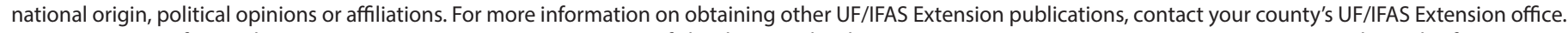
U.S. Department of Agriculture, UF/IFAS Extension Service, University of Florida, IFAS, Florida A \& M University Cooperative Extension Program, and Boards of County Commissioners Cooperating. Nick T. Place, dean for UF/IFAS Extension. 
Baker 2007), pond construction and design/shape (Kehoe 1993; Walker 1997; Persson and Wittgren 2003), load (Persson and Wittgren 2003), and the presence of a littoral zone (Stormwater Academy 2005).

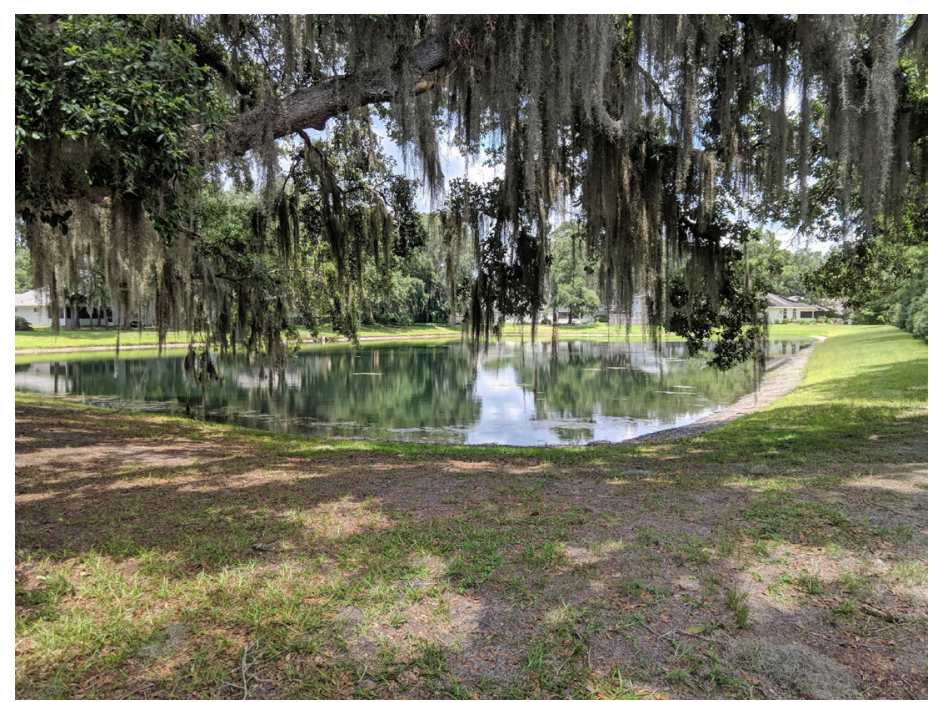

Figure 1. A typical stormwater pond in a Florida community. Note the bank erosion and lack of plantings along its perimeter.

\section{Potential for Plants to Enhance Functionality}

Incorporating plants into stormwater pond design and construction may help to improve the pond's watertreatment capacity by promoting other ecosystem services (Figure 2). For instance, plant buffer zones serve to stabilize shorelines, filter pollutants entering the water from the adjacent landscape, and take up nutrients (Mallin et al. 2002). Moreover, ponds without plant buffer zones tend to experience greater inputs of nutrient-rich grass clippings that can further degrade water quality (Ott et al. 2015). Deliberately placing desirable plants in stormwater ponds can also limit the establishment of undesirable invasive plants that create challenges for pond management (Mallin et al. 2002). Plantings both on the pond's shoreline and within the aquatic and littoral zones provide some of the same services, as well as the potential to limit unsightly algal blooms and enhance biodiversity, wildlife habitat, and nutrient cycling (Heisler et al. 2008; UF/IFAS 2008; Moore and Hunt 2012). Selecting and installing optimal plant species can promote these ecosystem services and increase the ecological functionality of stormwater ponds.

\section{Database for Plant Selection}

A variety of traits may be considered when choosing plant species for stormwater pond plantings. While aesthetics, native status, and commercial availability are some of the main considerations taken into account while choosing plant species, additional traits pertaining to a plant species' function and habitat requirements also may need consideration. This document describes a concise, easily understandable and readily accessible database to facilitate informed plant selection. The database is available through the Institutional Repository at the University of Florida (IR@UF) at: http://ufdc.ufl.edu/IR00010631/00001. The database presents a list of plant species and their corresponding traits organized into three separate overarching trait categories: aesthetics, function, and habitat. There is a separate table for traits within each of these categories. To determine whether a trait belonged within the aesthetics, function, or habitat table, we considered whether the trait most described the plant's appearance, how the plant impacts or responds to the environment, or the environmental conditions under which the plant grows best. The plant species contained within this database are mostly native to Florida (as determined by the UF/IFAS Non-Native Assessment Tool) and have been included based on their commercial availability, their aesthetic value, and their potential ability to promote the intended ecological functionality of stormwater ponds. The three overarching trait categories and the reasons they were selected are described below.

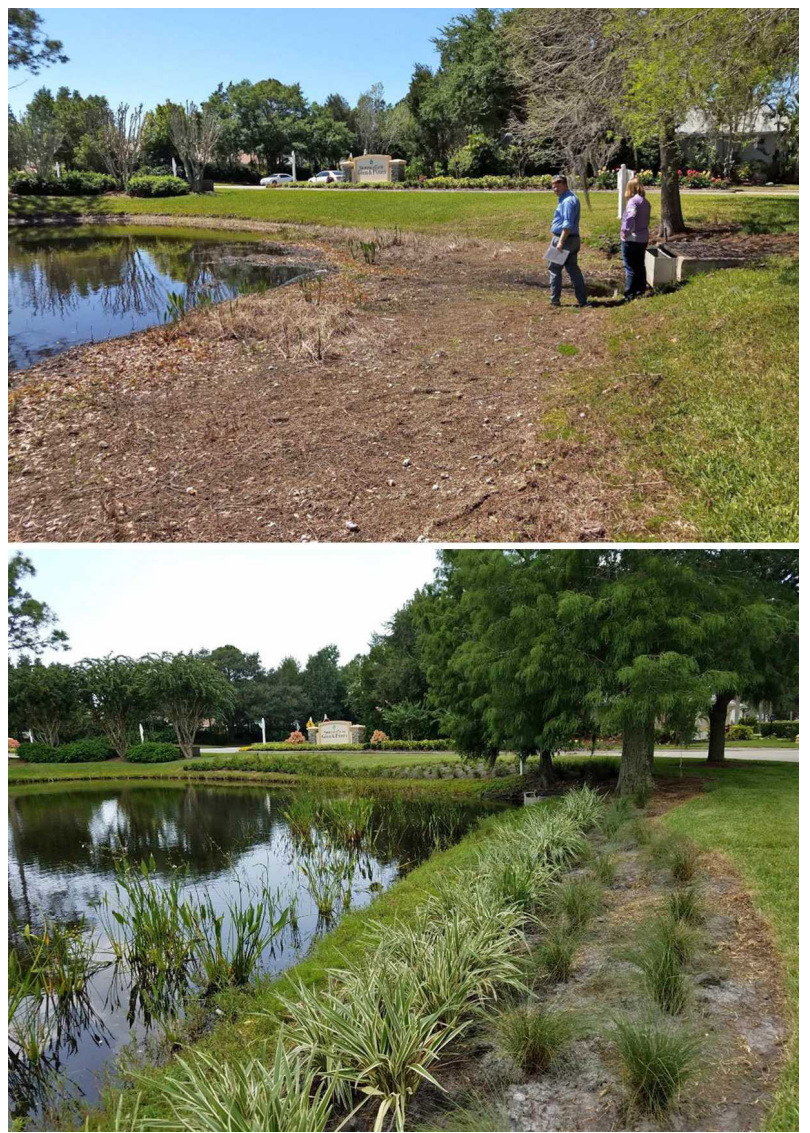

Figure 2. Before (top) and after (bottom) stormwater pond plantings. The pond on the left is more likely to experience soil erosion and nutrient-rich grass clippings entering the water, both of which can degrade water quality via increasing nutrient levels.

Credits: Basil lannone and Michelle Atkinson, UF/IFAS 


\section{Aesthetics}

The aesthetics, appearance, and/or visual quality of a plant is often the main driver behind plant selection. Characteristics such as color, growth form (shape), texture, and size are known to have aesthetic value, and landscapes with variations in these characteristics are generally found to be more aesthetically pleasing (Hansen and Hu 2016). The aesthetics table in the database includes a wide range of plant visual characteristics that allow consumers to select plants they find the most aesthetically pleasing while simultaneously considering traits presented in the remaining two database tables (function and habitat) (Table 1). Furthermore, aesthetic traits like flowering period, fruiting period, longevity, and phenology (evergreen vs. deciduous) inform consumers about specific life cycle traits that may cause changes in the plant's appearance over time so that consumers can make informed plant selections. Effective plant selection entails the consideration of not only aesthetics, but also plant function and habitat. The consideration of all three trait categories when selecting plants can create both an aesthetically pleasing and ecologically functional landscape.

Table 1. List of aesthetics variables present in the database.

\begin{tabular}{|l|l|}
\hline Aesthetics & Growth form \\
& Flowering period \\
& Fruiting period \\
& Longevity \\
& Range of max height (ft.) \\
Spread (ft.) \\
Growth rate \\
Evergreen vs. Deciduous \\
Color \\
\hline
\end{tabular}

\section{Function}

Plants can increase a pond's nutrient-removal capacity, while providing other ecosystem services and functions, such as bank stabilization, shoreline buffering to reduce pollutant input, attenuation of wave energy to prevent erosion, improvement of pest and disease resistance, and provision of food and habitat for wildlife. The function table provides information on the environmental functionality of the species in the database (Table 2). Information on root systems can be indicative of potential bank stabilization and erosion control. The Florida wetland indicator status recommends where the plants will best grow in or around a stormwater pond. Information on other traits is included to provide awareness about potential toxicity to other organisms, the plant's aggressiveness, and recommended management to achieve desired outcomes. Proper consideration of functional traits will help to ensure not only the attractiveness of stormwater ponds but also their ability to provide intended functions, such as flood control and pollutant removal and additional functions, such as improved habitat. Collectively, these services will lead to improved water quality and treatment, which is especially important in Florida communities with connectivity to protected waters.

Table 2. List of function variables present in the database.

\begin{tabular}{l|l} 
Function & Indicator status \\
& Root characteristic \\
Bank stabilization/erosion control \\
Water quality treatment \\
Wildlife benefit \\
Pollinators \\
Deer resistant \\
Pest/disease susceptibility \\
Cautions
\end{tabular}

\section{Habitat}

Proper plant selection also consists of taking into account each species' optimal growing conditions. The habitat table addresses this consideration by providing information on species' native status and the different environmental conditions in which they can establish and grow. These traits range from the plant's tolerance to flood and drought to the plant hardiness zones, type of soil, and soil $\mathrm{pH}$ in which the plant will thrive (Table 3). For example, knowing a plant's capacity to tolerate flooding and/or drought can help inform whether it is better suited for areas with or without standing water. A plant's hardiness zones are the geographically defined zones in which it is capable of growing, defined by its ability to withstand the zones' temperature extremes. Therefore, growers in various geographical regions can make sound plant selections based on the plants' hardiness zones. Finally, an understanding of optimal soil conditions for a given plant species will ensure that it is planted in conditions for which it is best suited (e.g., sand vs. clay or acidic vs. alkaline soils). Again, habitat traits should be considered in unison with function and aesthetic traits when selecting plant species for stormwater pond plantings.

Table 3. List of habitat variables present in the database.

\begin{tabular}{l|l} 
Habitat & Propagation \\
& Native/non-native \\
& Flood tolerance \\
Drought tolerance & Salinity tolerant \\
Optimal planting density \\
Hardiness zone \\
Soil pH \\
Soil type \\
Shade/sun \\
Commercial availability \\
Native habitat \\
Planting guidelines
\end{tabular}




\section{Data Compilation (Methodology)}

For this database, we compiled information on the aesthetic, function, and habitat traits of 82 plant species that can be planted in and/or around stormwater ponds. We identified suitable plant species from a suite of documents, including the Florida Fish and Wildlife Conservation Commission's "Plants for Lakefront Revegetation" (Rodgers n.d.) and Hansen and Hu's Florida-Friendly Plants for Stormwater Pond Shorelines (Hansen and Hu 2016). We confirmed the commercial availability for all 82 species with Florida nurseries, and we included them in each of the three trait tables (aesthetics, function, and habitat). The plant species are sorted and color-coded based on the stormwater pond zone best suited for their establishment and growth (Figure 3). Some cells in the database contain the symbol "--". This symbol occurs in cases where information is unavailable or because a trait may not apply to a certain plant. For example, a plant that does not produce fruit would show "--" for the trait "fruiting period." There is a metadata table in the database that defines stormwater pond zones and all of the traits that were documented for the 82 plant species. Also included in the database are links to the references from which we compiled the trait data. Below, we provide a hypothetical application of the database.

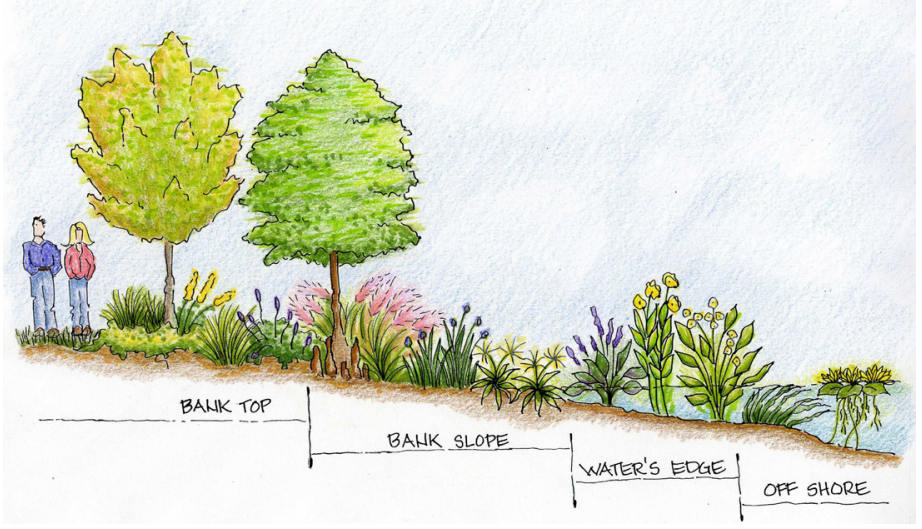

Figure 3. Illustration of stormwater pond planting zones along a moderate to gentle slope.

Credits: Gail Hansen, UF/IFAS

\section{Hypothetical Application}

The Homeowner's Association (HOA) of a neighborhood has received multiple complaints from residents about stormwater ponds with slipping muddy banks and large algal blooms after rains, indicative of excess nutrient input. The HOA decides to establish vegetation in and around the ponds to try to address these issues. A user should select plants for each zone of planting to help ensure pond success.

- Bank Top Zone: Select species with erosion control capabilities to limit nutrient and sediment inputs and to prevent further land erosion from incoming stormwater. Eragrostis spectabilis (Elliot's lovegrass), for example, comes highly recommended as a border plant; it is native and drought tolerant (indicating low maintenance requirement) and can be used for mass plantings.

- Bank Slope/Water's Edge: Select plants possessing traits that support bank stabilization and/or enhance water quality treatment. Inspection of the database reveals multiple suitable plant species. Canna flaccida (golden canna) is recommended for pond edges because it possesses traits that enhance both water quality and bank stabilization. Tripsacum dactyloides (Fakahatchee grass) is native, low-maintenance, and good for addressing bank erosion. Eleocharis cellulose (coastal spikerush) is recommended for stormwater ponds because it provides water quality treatment and it attracts birds and butterflies.

- Offshore: Schoenoplectus californicus (giant bulrush) is an evergreen that provides protection for shorelines from offshore wave action, attracts wildlife, and improves water quality.

This diverse selection of plants would do well in full-sun. All the plants are also commercially available and will exhibit blooming at all times of the year for residents to enjoy. This is but one illustration of how this database can help with plant selection in a way that strategically meets the objectives of a given planting project.

Application of this database will differ from situation to situation based upon the user's motivations. If appearance is the main goal, first review the aesthetics table for information on a plant's appearance, when it blooms, etc., and make selections based on aesthetic preference. Then, refer to the habitat table to ensure healthy establishment and refer to the function table to learn which plants provide the most desired additional benefits. If a pond is lacking functionality, first select plants based upon absent services that are needed, reference the habitat table for healthy establishment, and finally rule out less-than-ideal species based upon aesthetic preference. It is best to choose a variety of species for multiple zones and functions to establish a healthy and stable ecosystem.

\section{Additional Considerations}

Increasing plant biodiversity within stormwater ponds has potential benefits. Using more plant species in a pond will increase the number of traits present. This increase in traits will likely increase the number of benefits provided by stormwater pond plantings (e.g., bank stabilization plus pollinator and wildlife habitat vs. only bank stabilization). Increasing spatial heterogeneity in plantings can also have 
benefits. That is, there may be benefits to planting species in small species-specific clumps that are interspersed among one another. This interspersion of species can make it more difficult for pests to locate host species. In addition, should a given plant species die in a planting due to a pest outbreak or other disturbance such as drought, nearby plant species can help to provide intended functionality. For instance, in a multi-species planting where one species dies, the remaining species can still help to stabilize soils, enhance aesthetics, improve nutrient uptake, etc. In contrast, these functions would be entirely lost if the species that died was planted in a larger monoculture clump.

Plant maintenance intensity must also be considered. By nature, different plant species have varying maintenance needs. This database provides the information needed to choose plants that require minimal maintenance. Less maintenance can minimize or even eliminate the need for resource inputs beyond the plant establishment phase. This can reduce both the economic costs and the environmental costs that often result from intensive plant maintenance.

Although the database describes a suite of traits for many different plant species, more information is needed about how these plant species function, especially regarding their effect on water quality. Plant functionality is best understood through testable hypotheses and measurable results; therefore, this database provides an avenue for this understanding by presenting as much available information as possible on function.

\section{Conclusions}

Stormwater ponds are commonly used for stormwater management in developed areas all over the world. They play critical roles for flood control and water quality treatment, and they can provide ecological services to communities. Those ecological services can be enhanced with proper pond design and maintenance. By providing a comprehensive database of plant traits, we hope to help readers make informed plant selection decisions based on their own relative priorities.

This document and database are intended to serve as a living resource that will grow and improve over time. It already provides valuable information to aid in stormwater pond plant selection, particularly in Florida, but it is incomplete. If you would like to contribute supplemental information, please contact the authors of this document and/or UF/IFAS Sustainable Human and Ecological Development Group at shed@ifas.ufl.edu.

\section{Acknowledgements}

We would like to acknowledge the UF/IFAS Seed Fund and the CLCE Program Enhancement Grant for providing necessary funding. We would also like to thank Scott Wade from EarthBalance Native Nursery for assisting with data compilation.

\section{References}

Stormwater Academy. (2005). Quanifying the effect of a vegetated littoral zone on wet detention pond pollutant load reduction. BMP Trains Research and Publications. 18. https://stars.library.ucf.edu/bmptrains-research/18

Hansen, G., and S. Hu. 2019. Florida-Friendly Plants for Stormwater Pond Shorelines. ENH1215. Gainesville: University of Florida Institute of Food and Agricultural Sciences. http://edis.ifas.ufl.edu/ep476

Harper, H. H., and D. M. Baker. 2007. Evaluation of Current Stormwater Design Criteria within the State of Florida. Florida Department of Environmental Protection. Tallahassee, FL. Retrieved from: http://chesapeakestormwater.net/ wp-content/uploads/downloads/2012/01/Harper20and20Herr1.pdf

Heisler, J., P. M. Glibert, J. M. Burkholder, D. M. Anderson, W. Cochlan, W. C. Dennison, et al. 2008. "Eutrophication and harmful algal blooms: A scientific consensus." Harmful Algae 8(1) 3-13.

Kehoe, M. 1993. Water quality survey of twenty-four stormwater wet-detention ponds. Environmental Section, Southwest Florida Water Management District. Brooksville, Florida.

Mallin, M., S. Ensign, T. Wheeler, and D. Mayes. 2002. "Pollutant removal efficacy of three wet detention ponds." Journal of Environmental Quality 31 654-660.

Monaghan, P., S. Hu, G. Hansen, E. Ott, C. Nealis, and M. Morera. 2016. "Balancing the ecological function of residential stormwater ponds with homeowner landscaping practices." Environmental Management 58(5) 843-856.

Moore, T. L. C., and W. F. Hunt. 2012. "Ecosystem service provision by stormwater wetlands and ponds $-\mathrm{A}$ means for evaluation?" Water Research 46(20) 6811-6823. 
Ott, E., P. Monaghan, O. Wells, G. Hansen, L. Warner, and M. Atkinson. 2015. Strategies to encourage adoption of stormwater pond best management practices (BMPs) by homeowners. AEC552. Gainesville: University of Florida Institute of Food and Agricultural Sciences. http://edis.ifas. ufl.edu/wc214

Persson, J., and H. Wittgren. 2003. How hydrological and hydraulic conditions effect performance of ponds. Ecological Engineering 21 259-269.

Rodgers, J. Plants for Lakefront Revegetation. Florida Fish and Wildlife Conservation Commission. Tallahassee, FL. Retrieved from: https://www.pinellascounty.org/environment/watershed/pdf/adoptapond/Lakefront_Revegetation. pdf

Rushton, B., C. Miller, C. Hull, and J. Cunningham. 1997. Three design alternatives for stormwater detention ponds. Southwest Florida Water Management District. Brooksville, Florida. https://www.swfwmd.state.fl.us/sites/default/files/ medias/documents/design_alternatives_stormwater.pdf

UF/IFAS. 2008. Florida-friendly landscaping ${ }^{\mathrm{Tm}}$. http://ffl.ifas. ufl.edu/index.html

U.S. Environmental Protection Agency 2009. Stormwater wet pond and wetland management guidebook. Washington, D.C. Retrieved from: https://www3.epa.gov/npdes/pubs/ pondmgmtguide.pdf 